\title{
Produksi dan keuntungan usaha ternak puyuh sebagai pendapatan alternatif
}

\author{
Z. Poli ${ }^{1}$, F.H Elly ${ }^{1} *$, J. Husain ${ }^{2}$ \\ ${ }^{1}$ Fakultas Peternakan, Universitas Sam Ratulangi, Manado 95115 \\ ${ }^{2}$ Fakultas Pertanian, Universitas Sam Ratulangi, Manado 95115 \\ *Korespondensi (corresponding author) : femihelly@unsrat.ac.id
}

\begin{abstract}
ABSTRAK
Permintaan produk peternakan setiap tahun mengalami peningkatan, sehingga perlu diimbangi dengan ketersediaannya. Ternak unggas lokal termasuk ternak puyuh dapat dikembangkan guna mendukung kemandirian penyediaan pangan sumber protein hewani. Ternak puyuh memiliki prospek untuk dikembangkan mengingat Kota Manado sebagai tujuan wisata asing dan penduduknya cenderung meningkat. Remaja masjid Ulil Albab sebagai kelompok yang telah mengintroduksi usaha ternak puyuh. Permasalahannya sejauhmana keberhasilan $\mathrm{u}^{\mathrm{i}}$ saha ternak puyuh yang telah diintroduksi oleh Kelompok Remaja Masjid Ulil Albab. Pengkajian ini telah dilakukan dengan tujuan untuk mengetahui produksi dan keuntungan usaha ternak puyuh sebagai pendapatan alternatif. Metode penelitian adalah metode survey, penentuan sampel secara purposive. Data yang dikumpulkan adalah data primer dan data sekunder. Responden adalah kelompok remaja masjid Ulil Albab Kampus Unsrat yang ditentukan secara purposive sampling sebanyak 4 orang. Analisis data adalah deskriptif. Keberhasilan usaha peternakan puyuh tergantung pada karakteristik anggota kelompok. Usaha ternak puyuh yang dikembangkan sebanyak 200 ekor dengan produksi telur mengalami peningkatan setiap harinya. Pemasaran telur dilakukan secara online. Pembelian telur dilakukan untuk dikonsumsi oleh anggota keluarga. Produksi telur usaha ternak puyuh kelompok Remaja Masjid Ulil Albab mengalami peningkatan dan keuntungan yang diperoleh bernilai positif dengan nilai R/C 1,38 Saran, perlu dilakukan perluasan usaha agar konsumsi telur puyuh dapat meningkat dan mencapai maksimum.
\end{abstract}

Kata kunci: introduksi, ternak puyuh, usaha

\begin{abstract}
PRODUCTION AND PROFIT OF QUAIL FARMING AS AN ALTERNATIVE INCOME. The demand for livestock products every year had increased, so it needs to be balanced with its availability. Local poultry including quail can be developed to support self-sufficiency in providing food sources of animal protein. Quail had the prospect of being developed considering the city of Manado as a foreign tourist destination and its population tends to increase. Youth of Ulil Albab Mosque as a group that had introduced the quail farming business. The problem was the extent to which the success of the quail livestock business introduced by the Youth Group of Ulil Albab Mosque. This study was conducted with the aim of knowing the production and profit
\end{abstract}


of quail farming as source of alternative income. The research method was survey method, the sample was determined purposively. The data collected were primary and secondary data. Respondents were youth group of the Ulil Albab Mosque on the Unsrat Campus determined by purposive sampling of 4 people. The data analysis was descriptive. The success of quail business depends on the characteristics of the group members. The business was developed as many as 200 heads with egg production increasing every day. Egg marketing was through online. Quail egg consumers were housewives. Purchases of eggs were made for consumption by family members. In conclusion, egg production of quail business of the Ulil Albab Mosque Youth group increased and the profits obtained were positive with R/C value of 1.38 Suggestion, it is necessary to expand the business so that the maximum consumption of quail eggs can be increased.

Key words: introduction, quail livestock, business

\section{PENDAHULUAN}

setiap $\begin{array}{rr}\text { Produk peternakan yang diminta } \\ \text { tahunnya mengalami }\end{array}$ peningkatan. Hal tersebut sebagai dampak adanya peningkatan beberapa faktor diantaranya jumlah penduduk dan pendapatan masyarakat. Fenomena ini menunjukkan ketersediaan produk peternakan sangat dibutuhkan dalam mengimbangi laju permintaan tersebut. Produk peternakan (daging, telur dan susu) sangat penting bagi peningkatan kualitas sumberdaya manusia. Ternak unggas lokal termasuk ternak puyuh dapat dikembangkan guna mendukung kemandirian penyediaan pangan sumber protein hewani (Elly et al. 2015 dan Elly et al 2018). Produksi produk unggas (daging dan telur) peningkatannya lambat, sehingga alternatif untuk memenuhi permintaan produk unggas tersebut dapat disubstitusi oleh produk ternak puyuh. Penduduk kota Manado yang cenderung meningkat (BPS Sulut, 2018), yang berdampak meningkatkan permintaan terhadap produksi peternakan. Kondisi tersebut sangat menunjang prospek pengembangan usaha ternak puyuh. Kota Manado adalah salah satu kota tujuan wisata penduduk asing, sehingga berpeluang dalam peningkatan penyediaan produk peternakan termasuk produk puyuh. Daging dan telur puyuh dapat diandalkan dalam mensuplai kebutuhan produk peternakan sebagai sumber protein hewani.

Berdasarkan pemikiran dan permasalahan di atas maka usaha ternak puyuh telah diintroduksi dan dikembangkan oleh salah satu kelompok yaitu Remaja Masjid Ulil Albab. Ternak puyuh saat ini mulai digemari dan dikembangkan oleh masyarakat. Konsumen telur puyuh telah mengalami peningkatan dan semakin digemari oleh sebagian masyarakat (Sanjaya et al. 2016). Peningkatan minat dan kegemaran masyarakat terhadap telur puyuh merupakan peluang bagi pengembangan bisnis usaha ternak puyuh. Daging puyuh juga mulai digemari dan dimanfaatkan sebagai sumber protein hewani asal ternak. Permasalahannya sejauhmana keberhasilan usaha ternak puyuh yang telah diintroduksi oleh Kelompok Remaja Masjid Ulil Albab. Berdasarkan permasalahan tersebut maka penelitian ini dilakukan dengan tujuan untuk mengetahui produksi telur 
yang dihasilkan setelah introduksi usaha ternak puyuh dalam menunjang konsumsi produk peternakan.

\section{METODE PENELITIAN}

Metode penelitian adalah metode survey dengan pendekatan Studi Kasus terhadap usaha ternak puyuh. Data yang dikumpulkan adalah data primer dan data sekunder. Responden adalah kelompok Remaja Masjid Ulil Albab Kampus Unsrat yang ditentukan secara purposive sampling yaitu sebanyak 4 orang. Variabel yang diukur adalah jumlah ternak puyuh sebanyak 200 ekor, luas kandang, pakan yang diberikan, produksi telur puyuh dan jumlah yang dipasarkan. Analisis data adalah deskriptif.

\section{HASIL DAN PEMBAHASAN}

Keberhasilan usaha peternakan puyuh tergantung pada karakteristik anggota kelompok Remaja masjid Ulil Albab. Karakteristik anggota kelompok diantaranya Pendidikan dan umur responden. Umur responden berkisar antara 21-22 tahun yang menunjukkan masih dikategorikan umur produktif. Masyrakat seperti peternak yang dikategorikan umur produktif adalah mereka yang memiliki peluang tinggi dalam mengadopsi inovasi teknologi (Mauludin et al. 2012). Menurut beberapa ahli bahwa umur produktif secara psikologi memiliki kelebihan. Kelebihan dimaksud diantaranya senang mencoba hal-hal baru, lebih menguasai teknologi, mampu belajar mandiri maupun secara berkelompok, serta memiliki sikap cepat mengadopsi suatu inovasi (Zakiah et al. 2017).

Keberhasilan usaha peternakan puyuh juga tergantung pada tingkat Pendidikan anggota kelompok Ulil Albab. Tingkat pendidikan yang dimaksud dalam penelitian ini adalah tingkat pendidikan formal yang diikuti oleh anggota kelompok. Hasil penelitian menunjukkan bahwa 100 persen responden lulus SMA. Menurut Zakiah et al (2017) bahwa masyarakat dengan tingkat pendidikan lulusan SMA menunjukkan masyarakat tersebut memiliki kesadaran tentang pendidikan adalah penting.

Usaha ternak puyuh yang dikembangkan anggota kelompok sebanyak 200 ekor puyuh betina. dengan produksi telur mengalami peningkatan setiap harinya. Ternak puyuh dibudidayakan sejah umur 5 minggu. Kandang yang digunakan adalah kandang kotak yang menggunakan ram. Tipe kandang seperti ini disebut sebagai cage. Cage merupakan kandang berbentuk kotak, terbuat dari kawat, bambu, reng dan kayu. Ukurannya dalam satu flock adalah disesuaikan dengan jumlah ternak puyuh yang dikembangkan. Setiap satu flock kandang dalam penelitian ini berisi 50 ekor ternak puyuh. Ukuran satu flock adalah 60x 120x35 cm, terdiri dari 4 flock dan dua flock dibuat bersusun. Keadaan kandang milik anggota kelompok dapat dilihat pada Gambar 1. 


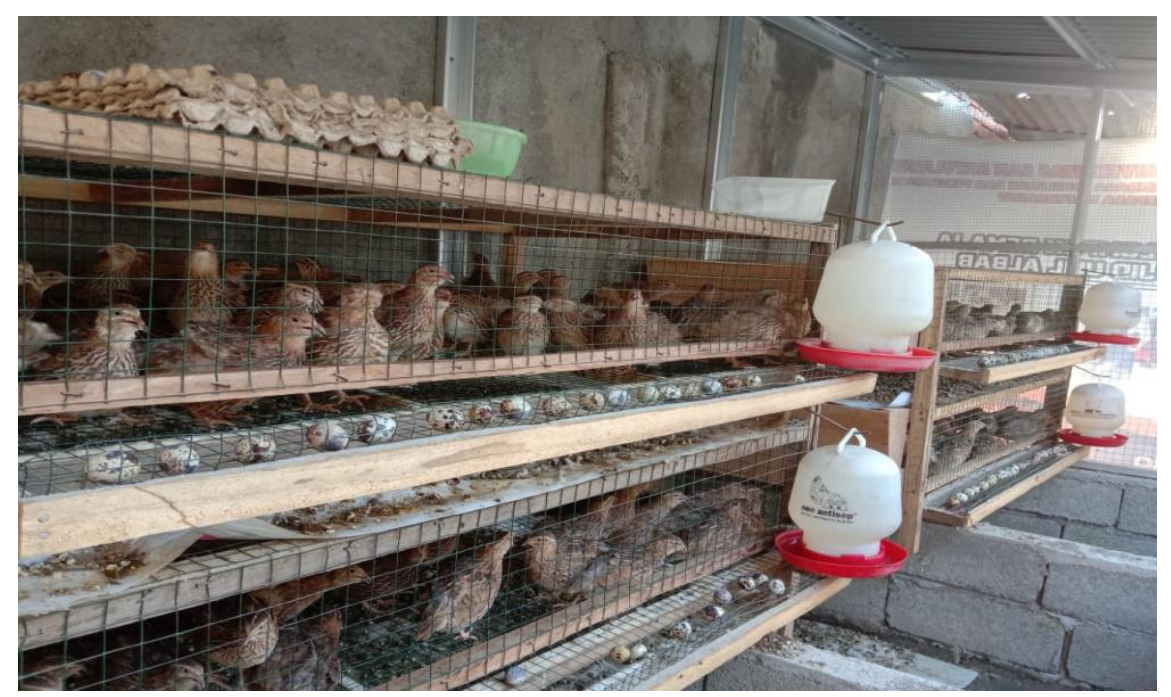

Gambar 1. Kandang Ternak Puyuh

Gambar 1 menunjukkan kondisi kendang ternak puyuh yang tidak membutuhkan lahan yang luas. Kandang dibuat bersusun sehingga tidak membutuhkan tempat yang besar. Setiap kotak kendang diletakkan sebuah tempat minum yang diberikan secara adlibitum. Kandang ternak puyuh dibuat sebagai untuk berlindung, beristirahat, makan, minum, melindungi dari cuaca ekstrim, dan predator yang dapat membahayakan ternak puyuh. Keadaan kandang diupayakan memberikan kenyamanan dan keamanan bagi ternak puyuh. Hal ini dapat berdampak terhadap produksi telur puyuh yang dihasilkan secara maksimal. Kandang menurut Destia et al (2017) merupakan salah satu faktor lingkungan yang berdampak terhadap produktivitas ternak puyuh. Kandang yang baik dan sesuai dengan kondisi ternak puyuh selain memberikan dampak pada kuantitas telur juga terhadap kualitas telur yang dihasilkan.

Produksi telur puyuh sesuai hasil penelitian dapat dilihat pada Tabel
1. Produksi telur sesuai hasil penelitian dihitung berdasarkan jumlah telur yang dihasilkan setiap hari. Hal ini seperti yang dilakukan dalam penelitian Hanifah et al (2019). Produksi telur dipengaruhi beberapa faktor diantaranya : faktor genetik, pakan, perkandangan, suhu, rontok bulu, penyakit dan stress (Wahyuri et al. 2014). Data Tabel 1 menunjukkan bahwa produksi telur puyuh mengalami peningkatan setiap minggunya. Produksi telur puyuh tergantung pada pakan yang diberikan. Hasil penelitian menunjukkan bahwa pakan yang diberikan terhadap ternak puyuh adalah pakan pabrikan (SP-22) yang ditambahkan probiotik. Pakan pabrikan atau pakan komersial yang biasa digunakan peternak puyuh (Latif et al. 2017 dan Nurrofingah et al. 2017) bahwa sebagian peternak puyuh menggunakan pakan komersial. Pakan diberikan dua kali sehari yaitu pagi dan sore hari, sebanyak 24 gram per ekor perhari. 
Tabel 1. Produksi Telur Puyuh Milik Kelompok Remaja Masjid Ulil Albab

\begin{tabular}{ccr}
\hline No. & Umur Ternak Puyuh (Minggu) & Jumlah Produksi (Butir/Minggu) \\
\hline 1 & 7 & 121 \\
2 & 8 & 523 \\
3 & 9 & 919 \\
4 & 10 & 1.003 \\
5 & 11 & 1.037 \\
6 & 12 & 1.105 \\
7 & 13 & 1.113 \\
8 & 14 & 1.196 \\
\hline
\end{tabular}

Produksi telur puyuh dihitung mulai produksi minggu ke tujuh. Kondisi ini menunjukkan bahwa pengelolaan usaha ternak puyuh dilakukan dengan baik sehingga produksi telur mengalami peningkatan. Telur yang dihasilkan semuanya terjual dengan harga Rp 500 per butir.

Hasil penelitian menunjukkan bahwa pemasaran telur puyuh dilakukan secara online. Kondisi ini menunjukkan bahwa penjualan telur dilakukan dengan memanfaatkan digital marketing. Menurut Rusmanah et al (2019), digital marketing adalah suatu bentuk program promosi dan pencarian peluang pasar melalui media digital secara online.
Promosi dan pencarian peluang pasar ini dengan memanfaatkan berbagai sarana, contohnya adalah jejaring sosial media (Rusmanah et al. 2019). Menurut Rosidawanti et al (2015), semua responden menggunakan internet dengan tingkat penggunaan yang tinggi.

Proses penjualan telur dimulai dari promosi melalui online, kemudian konsumen melakukan orderan sesuai dengan kebutuhan. Pengepakan telur dilakukan setelah ada orderan dari konsumen (Gambar 2). Telur dijual Rp 10.000 per packing dengan isi sebanyak 20 butir telur. Packing dibuat dengan mencantumkan label kelompok Remaja Masjid Ulil Albab.

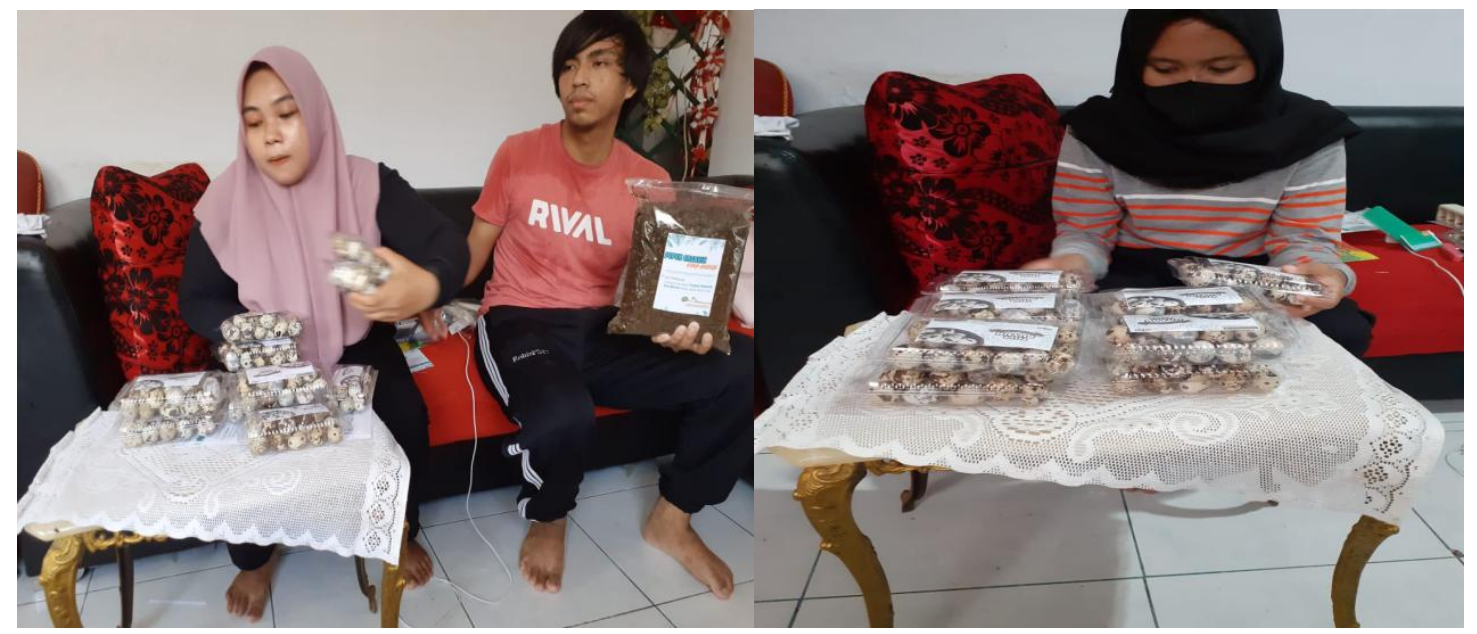

Gambar 2. Melayani Pemasaran Telur Secara Online 


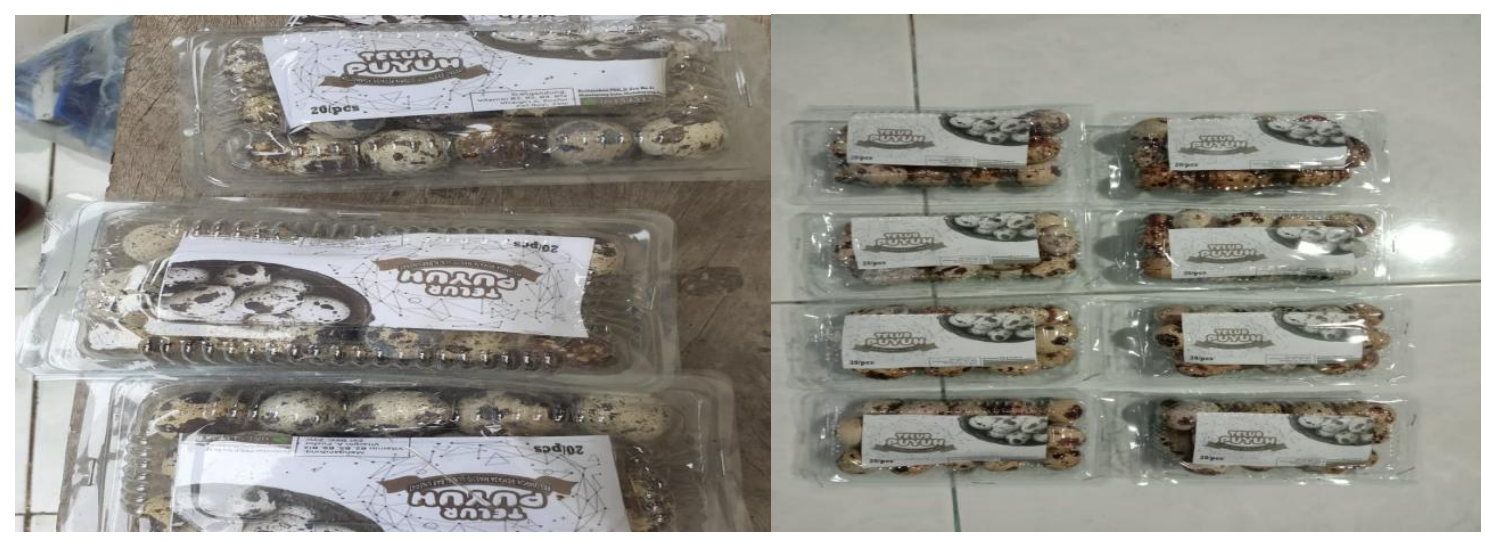

Gambar 3. Telur Puyuh Yang Dipasarkan

Konsumen telur puyuh adalah ibu rumahtangga. Pembelian telur dilakukan untuk dikonsumsi oleh anggota keluarga. Kondisi ini menunjukkan bahwa telur puyuh memiliki peluang pasar karena permintaannya dilakukan oleh ibu-ibu rumahtangga. Menurut Fathurohman et al (2014) bahwa telur puyuh memiliki peluang pasar yang cukup memadai yang dilihat dari selisih permintaan dan penawaran. Kendala yang dihadapi kelompok Remaja Masjid Ulil Albab adalah minat ibu-ibu rumahtangga cukup tinggi tetapi seringkali permintaan telur puyuh tidak dapat dipenuhi. Perluasan usaha dalam hal ini sangat dibutuhkan. Ibu-ibu melakukan permintaan secara online, seperti diketahui saat terjadinya pandemic covid 19 maka pemerintah membatasi orang untuk keluar rumah. Alternatif pembelian yang dilakukan adalah melalui online.

Keuntungan usaha ternak puyuh dapat diandalkan sebagai sumber pendapatan bagi Kelompok Remaja Mesjid Ulil Albab. Keuntungan dihitung berdasarkan selisih antara penerimaan (penjualan telur) dan biaya yang dikeluarkan dalam proses produksi ternak puyuh. Keuntungan dalam penelitian ini dihitung selama 8 minggu produksi telur puyuh yang dihasilkan seperti pada Tabel 2.

Tabel 2. Keuntungan Penjualan Telur Puyuh Milik Kelompok Remaja Masjid Ulil Albab

\begin{tabular}{|c|c|c|}
\hline No. & Uraian & Jumlah (Rp/8 minggu) \\
\hline 1 & Produksi Telur & $7.017,00$ \\
\hline 2 & Penerimaan & $3.508 .500,00$ \\
\hline \multirow[t]{5}{*}{3} & Biaya ( $\mathrm{Rp} / 8 \mathrm{minggu})$ & \\
\hline & a. Pakan & $1.400 .000,00$ \\
\hline & b. Tenaga Kerja & $1.068 .750,00$ \\
\hline & c. Penyusutan biaya tetap & $64.649,52$ \\
\hline & Total Biaya & $2.533 .399,52$ \\
\hline 4 & $\begin{array}{l}\text { Keuntungan (Penerimaan- } \\
\text { Biaya) }\end{array}$ & $975.100,48$ \\
\hline 5 & $\mathrm{R} / \mathrm{C}$ & 1,38 \\
\hline
\end{tabular}


Keuntungan usaha ternak puyuh dalam penelitian ini (Tabel 1) dihitung dari proses produksi selama 8 minggu. Penerimaan sebesar Rp 3.508.500 diperoleh dari penjualan telur yang dihasilkan selama 8 minggu. Biaya produksi terdiri dari biaya pakan, biaya tenaga kerja dan biaya penyusutan kandang, peralatan usaha ternak puyuh dan sewa lahan. Biaya pakan adalah biaya terbesar (55,26 persen), kemudian diikuti oleh biaya tenaga kerja $(42,19$ persen) dan biaya penyusutan hanya sebesar 2,55 persen). Hasil penelitian Wangefela et al. (2018) menunjukkan bahwa tenaga kerja yang digunakan untuk usaha ternak puyuh adalah $\mathrm{Rp}$ 2.800.000 per bulan. Sedangkan pada penelitian ini tidak menggunakan tenaga kerja sewa tetapi biaya tenaga kerja dihitung berdasarkan upah yang berlaku yaitu Rp 100.000 per hari. Keuntungan yang diperoleh positif dengan $\mathrm{RC}$ ratio sebesar 1,38. Kondisi ini menunjukkan bahwa usaha ternak puyuh memberikan keuntungan bagi kelompok Remaja Mesjid Ulil Albab termasuk bagi peternak lainnya. Panekenan et al (2013) dalam penelitiannya menganalisis keuntungan usaha ternak puyuh dalam satu periode sehingga besarnya keuntungan tidak bisa digunakan sebagai pembanding dengan penelitian ini. Menurut Hanifah et al (2019) keuntungan yang dipengaruhi oleh produksi telur puyuh dan biaya konsumsi pakan.

\section{KESIMPULAN}

Berdasarkan hasil penelitian dapat disimpulkan bahwa produksi telur usaha ternak puyuh kelompok Remaja Masjid Ulil Albab mengalami peningkatan per minggu dan keuntungan yang diperoleh positif dengan nhlai R/C 1,38
Berdasarkan hasil penelitian maka disarankan bahwa perlu dilakukan perluasan usaha agar konsumsi telur puyuh dapat meningkat dan mencapai maksimum.

\section{UCAPAN TERIMA KASIH}

Terima penulis sampaikan kepada DRPM yang telah memberikan bantuan dana untuk pelaksanaan kegiatan melalui skim PKM.

\section{DAFTAR PUSTAKA}

BPS, Sulut. 2018. SULUT Dalam Angka. Badan Pusat Statistik Sulawesi Utara, Manado.

Destia, M., D Sudrajat, dan E Dihansih. 2017. Pengaruh rasio panjang dan lebar kandang terhadap produktivitas burung puyuh (Coturnix coturnix japonica) periode produksi. Jurnal Peternakan Nusantara 3(2): 5764.

Elly, F.H., M.A.V. Manese., J.C. Loing., R. Pomolango, A. Makalew dan E. Wantasen. 2018. Food consumption of livestock products by household coast in South Bolaang Mongondow Regency, North Sulawesi, Indonesia. Advance in Nutrition of Food Science 3 (1) : 1-5.

Elly, F.H., M. Manese., N.M. Santa and I.D.R. Lumenta. 2015. Analysis of livestock product consumption coastal household in North Minahasa Regency. Procedia Food Science 3 : 364-370.

Fathurahman, R., A. Bakar dan L. Fitria. 2014. Analisis kelayakan usaha peternakan burung puyuh di Daerah Pasir Kawung Cileunyi 
Kabupaten Bandung. Jurnal Reka Integra 02 (3) : 1-12.

Hanifah, F.N. K. Soepranianondo, Soeharsono, A.Al. Arif, W. P. Lokapirnasari, N. Harijani, S. Hadijah, dan M. R. T. Hutabarat. 2019. Performa produksi dan analisis usaha puyuh (coturnix coturnix japonica) yang diberi substitusi black soldier fly larvae (BSFL) pada pakan komersil. Jurnal Sain Veteriner, 37 (2) : 219-226.

Latif, S., E. Suprijatna dan D. Sunarti. 2017. Performans produksi puyuh yang di beri ransum tepung limbah udang fermentasi. Jurnal Ilmu-Ilmu Peternakan, 27 (3) : $44-53$.

Mauludin, M.A., S. Winaryanto dan S. Alim. 2012. Peran kelompok dalam mengembangkan keberdayaan peternak sapi potong (Kasus di Wilayah Selatan Kabupaten Tasikmalaya). Jurnal Ilmu Ternak 12 (1) : 1-8.

Nurrofingah, U., Sumiati dan Y. Retnani. 2017. Evaluasi aktivitas antioksidan jus kulit nanas dengan ransum berbeda terhadap performa puyuh (Cortunix cortunix japonica). Buletin Makanan Ternak, 104(1): 30-44.

Panekenan, J.O., J. C. Loing dan B. Rorimpandey. 2013. Analisis keuntungan usaha beternak puyuh di Kecamatan Sonder Kabupaten Minahasa. Jurnal Zootek 32 (5): 1-10.

Rosidawanti, D., U. Yunasaf dan S. Alim. 2015. hubungan karakteristik penyuluh dengan penggunaan media informasi dan teknologi sebagai sumber informasi penyuluh di bidang peternakan. Students e-Journal 4 (2) : 1-15.

Rusmanah, E, A. W. Irawan, dan F. Andria. 2019. Implementasi digital marketing guna peningkatan peluang pasar produksi hasil ternak puyuh masyarakat Desa Galuga. Jurnal ABM Mengabdi,6,(1) : 14-25.

Sanjaya, B., Amalia dan H. Jasid. 2016. Analisis kelayakan burung puyuh petelur (Cortunix-cortunix japonica) di Kelurahan Tebing Tinggi Okura Kecamatan Rumbai Pesisir Kota Pekan Baru. Jurnal Ilmiah Pertanian 13 (1) : 47-58.

Wahyuri, M., E. Rahmadani dan Elfawati. 2014. Manajemen teknis produksi peternakan puyuh (studi Kasus di Peternakan Masagena Kecamatan Tenayan Raya). Jurnal Peternakan, 11 (1) : $8-21$.

Wangefela, L., N. M. Santa, A. H. S. Salendu, dan L. S. Kalangi. 2018. analisis margin of safety usaha peternakan puyuh "merryland" di Desa Kali Kecamatan Pineleng Kabupatn Minahasa. Jurnal Zootek 38 (1): 183-191.

Zakiah., A. Saleh dan K. Matindas. 2017. Gaya Kepemimpinan dan perilaku komunikasi GPPT dengan kapasitas kelembagaan sekolah peternakan rakyat di Kabupaten Muara Enim. Jurnal Penyuluhan 13 (2) : 133-142. 